\title{
New records of Guernella Richard 1892 (Cladocera, Macrothricidae) from Brazil
}

\author{
Elmoor-Loureiro, LMA. ${ }^{\mathrm{a} *}$, Lopes, PM. ${ }^{\mathrm{b}}$, Jesus, SB. ${ }^{\mathrm{c}}$, Bozelli, RL. ${ }^{\mathrm{b}}$ and Aleluia, FTF. ${ }^{\mathrm{c}}$

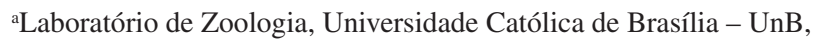 \\ QS 7, Lote 1, Bloco M, sala 331, CEP 71966-700, Taguatinga, DF, Brazil \\ ${ }^{b}$ Laboratório de Limnologia, Universidade Federal do Rio de Janeiro - UFRJ, \\ Prédio CCS, bloco A, subsolo, sala A0-008, Ilha do Fundão, CEP 21941-590, Rio de Janeiro, RJ, Brazil \\ 'Bioconsultoria Ambiental Ltda., Núcleo Integrado de Estudos em Zoologia - NIEZ, \\ Instituto de Ciências Biológicas, Universidade Católica do Salvador - UCSal, \\ Av. Pinto de Aguiar, CEP 40080-121, Patamares, Salvador, BA, Brazil \\ *e-mail: lourdes@ucb.br
}

Received September 14, 2009 - Accepeted September 29, 2010 - Distributed August 31, 2010

(With 5 figures)

Guernella raphaelis Richard 1892 was described originally from Congo and, for a long time, it has been considered the single species of the genus, with circumtropical distribution (Thomas, 1961; Smirnov, 1992). Based on the analysis of Richard's sample, as well as specimens from Asia and the Southern United States, Frey (1988) suggested that these populations belong to different species. Important morphological variations were also reported for specimens from Argentina (Paggi, 1976) and Mexico (Elías-Gutiérrez et al., 2001; Garfias-Espejo and Elías-Gutiérrez, 2003), which support the idea that Guernella raphaelis is a complex of species. For this reason, non-African populations should be better named as Guernella cf. raphaelis.

In South America, the occurrence of Guernella raphaelis was reported from Argentina (Paggi, 1976, 1987), Venezuela (Zoppi de Roa and Vazquez, 1991), Suriname (Frey, 1988), and Brazil (upper Paraná River floodplain - Serafim Jr. et al., 2003, Paraguay River - Hollwedel et al., 2003). There is also a record of Guernella sp. from Curuá-Una Reservoir, Pará (Robertson, 1980).

The present paper aims to present new records of Guernella cf raphaelis from Brazil: plankton sample collected near Ximboá, Araguaia River, Tocantins (appr. 6 24' 22" S; 48 32' 8" W), in 2003, leg. by M.S.R. Ibañez; plankton sample from Fish River, Itagibá, Bahia (14 $11^{\prime}$ ' ' S and 39 39' 56" W), in October/2008, coll by S. B. de Jesus and plankton sample from Atoleiro pond, Restinga of Jurubatiba National Park, Rio de Janeiro ( $22^{\circ} 22^{\prime} 30^{\prime \prime} \mathrm{S}$ and $41^{\circ} 30^{\prime} 42^{\prime \prime} \mathrm{W}$ ), coll. by P.M. Lopes.

The voucher specimens were deposited in the collections of the Laboratory of Zoology at the Universidade Católica de Brasília, Laboratory of Limnology at the Universidade Federal do Rio de Janeiro, and in the Núcleo Integrado de Estudos em Zoologia (NIEZ) at the Universidade Católica do Salvador.

The analysed specimens (Figure 1) agree with the general description of Guernella raphaelis (Smirnov, 1992), but present some particularities in comparison to African, Mexican, and Argentinean populations (as presented in Grafias-Espejo and Elías-Gutiérrez, 2003). Brazilian specimens share some characteristics with the Argentinean and Mexican populations, which are not found in specimens from Africa: four setae on IDL of trunk limb I (Figure 2) and eight scrapers on trunk limb

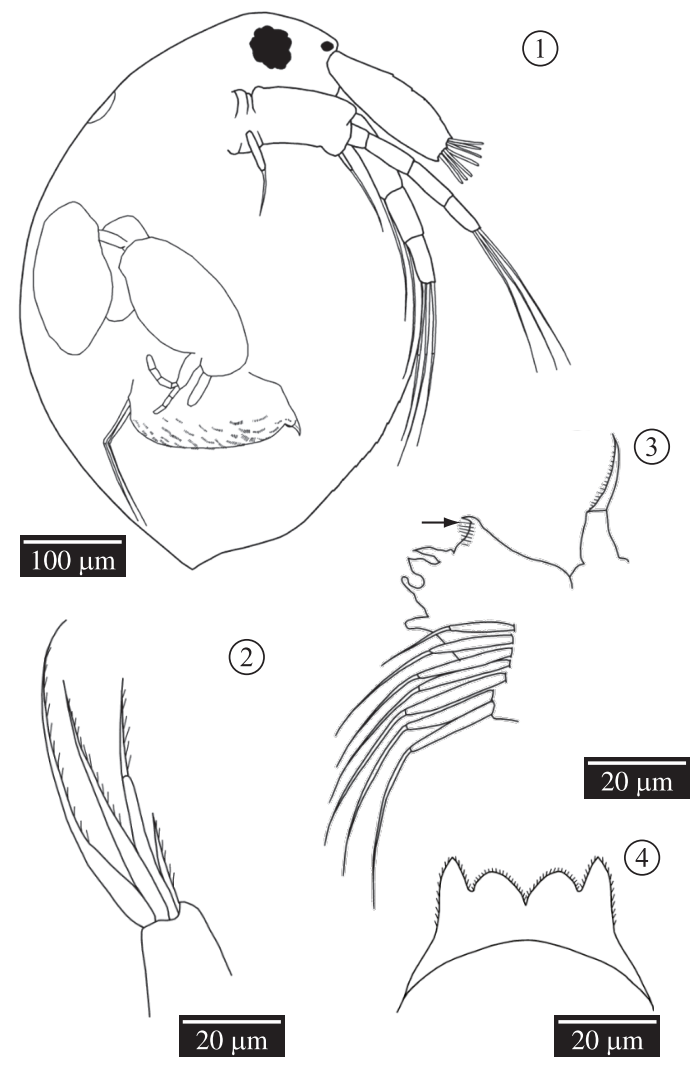

Figures 1-4. Guernella cf. raphaelis from Brazil, parthenogenetic female from Atoleiro Pond, Rio de Janeiro. 1) general view; 2) internal distal lobe (IDL) of trunk limb I; 3) gnathobase of trunk limb II (arrow indicates the acute protuberance); 4) postabdominal claw with ciliated lamella, dorsal view. 


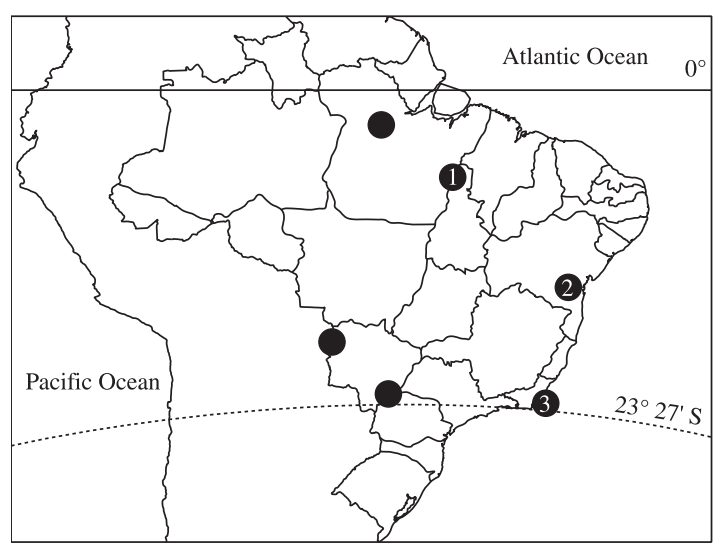

Figure 5. Distribution of Guernella cf. raphaelis in Brazil, showing previous $(\bullet)$ and present records. 1) Araguaia River, TO; 2) Fish River, BA; 3) Atoleiro Pond, RJ.

II. The gnathobase of the trunk limb II (Figure 3) is similar to the Mexican specimens, presenting an acute protuberance near gnathobase and four gnathobasic setae (no available information for Argentinean specimens). The ciliated lamella in the postabdominal claws, until now only reported for Argentinean populations (Paggi, 1976), was observed in the studied specimens (Figure 4). Our results suggest that South American populations belong to the same taxon.

There are no descriptions or comments on morphology for previous Brazilian records of Guernella (Robertson, 1980; Serafim Jr. et al., 2003; Hollwedel et al., 2003), which do not allow comparisons with our specimens.

The present data indicate that Guernella cf. raphaelis is widely distributed in Brazil (Figure 5), although not frequently reported.

Acknowledgements - The authors thank M.S.R. Ibañez, Mirabela Brasil LTDA, Bioconsultoria Ambiental LTDA, Vale
S.A., IBAMA, and ICMBio for making possible the collection of the specimens.

\section{References}

ELÍAS-GUTIÉRREZ, M., SMIRNOV, NN., SUÁREZ-MORALES, E. and DIMAS-FLORES, N., 2001. New and little known cladocerans (Crustacea: Anomopoda) from Southeastern Mexico. Hydrobiologia, vol. 442, no. 1-3, p. 41-54.

FREY, DG., 1988. Are there tropicopolitan macrothricid Cladocera? Acta Limnologica Brasiliensia, vol. 2, p. 513-525.

GARFIAS-ESPEJO, T. and ELÍAS-GUTIÉRREZ, M., 2003. Taxonomy and distribution of Macrothricidae (Crustacea: Anomopoda) in southeastern Mexico, northern Guatemala and Belize. Anales del Instituto de Biologia, vol. 74, no. 2, p. 105-134. (Serie Zoologia)

HOLLWEDEL, W., KOTOV, AA. and BRANDORFF, GO., 2003. Cladocera (Crustacea: Branchiopoda) from the Pantanal (Brazil). Arthropoda Selecta, vol. 12, no. 2, p. 67-93.

PAGGI, JC., 1976. Cladoceros Macrothricidae nuevos para la fauna Argentina. Physis, vol. 35, no. 91, p. 103-112.

ROBERTSON, BA., 1980. Composição, abundância e distribuição de Cladocera (Crustacea) na região de água livre da represa de Curuá-Una, PA. Manaus: Instituto Nacional de Pesquisas da Amazônia. 105 p. [Dissertação de Mestrado]

SERAFIM Jr., M., LANSAC-TÔHA, FA., PAGGI, JC., VELHO, LFM. and ROBERTSON, BA., 2003. Cladocera fauna composition in a river-lagoon system of the upper Paraná river floodplain, with a new record for Brazil. Brazilian Journal of Biology, vol. 63, no. 2, p. 349-356.

SMIRNOV, NN., 1992. The Macrothricidae of the world. Amsterdam: SPB Academic Publishing. 143 p.

THOMAS, IF., 1961. The Cladocera of the swamps of Uganda. Crustaceana, vol. 2, no. 2, p. 108-125.

ZOPPI DE ROA, E. and VASQUEZ, W., 1991. Additional cladoceran records for Mantecal and new for Venezuela. Hydrobiologia, vol. 225 , no. 1 , p. $45-62$. 